\title{
A Political History of Bektashism from Ottoman Anatolia to Contemporary Turkey
}

\section{ALBERT DOJA}

The origin of the Bektashi order of dervishes belongs to the many Sufi movements of Islam that developed in the Middle East from the eleventh and twelfth centuries onwards. ${ }^{1}$ At this time, a number of missionary precursors, known as the Saints of Khorassan, infiltrated Anatolia where they paved the way to the dervish groups like the Bektashis. The name of the order is derived from the legendary founder Hadji Bektash, even though, as in many other cases concerning Sufi hagiography, Hadji Bektash was not the actual founder of the order but a patron saint chosen at a later date. It is thought that he came originally from Khorassan in northeast Iran and lived in Anatolia in the second half of the thirteenth century. ${ }^{2}$ The description of his Vilayet-Name corresponds to that of the typical wandering dervishes known as Iranian Kalenders or Anatolian Abdals in the thirteenth and fourteenth centuries. ${ }^{3}$ The dervishes who followed him are called Abdal and from the very start, he is called "leader" (Pir) of Anatolian Abdals.

Apparently Bektashism started during the thirteenth and fourteenth centuries as a mixture of shamanism inherited from

\footnotetext{
-ALBERT DOJA (Ph.D., EHESS; University of Paris) is senior research fellow, College of Humanities, University of Limerick, Ireland. His articles have appeared in Journal of the History of Ideas, Social Science Information, Anthropology Today, History and Anthropology, Reviews in Anthropology, Critique of Anthropology, Social Anthropology, The European Legacy, Rural History, Anthropos, Anthropological Quarterly, and others. Special interests include anthropology of religion, politics of kinship and social organization, anthropology of history, structuralism and poststructuralism.
}

1. Ahmet T. Karamustafa, God's Unruly Friends: Dervish Groups in the Islamic Later Middle Period 1200-1550 (Salt Lake City, Utah: University of Utah Press, 1994).

2. Irene Melikoff, Hadji Bektach, un mythe et ses avatars: genèse et évolution du soufisme populaire en Turquie, Islamic History and Civilization Series, vol. 20 (Leiden: Brill, 1998).

3. Ahmet Yashar Ocak, "Remarques sur le rôle des derviches kalender dans la formation de l'ordre bektashi," in Bektachiyya: études sur l'ordre mystique des Bektachis et les groupes relevant de Hadji Bektach, ed. Alexandre Popovic and Gilles Veinstein (Istanbul: Isis, 1995). 
the Turkic tribes of Khorassan, mixed with popular beliefs in such a way as to appeal to villagers and the lower class of the Anatolian population. Bektashism must have mingled with local beliefs, and it is not surprising that besides different Sufi doctrines and practices, many religious traditions may have contributed to the development and appearance of Bektashism, including ancient Turkic elements preserving pre-Islamic and non-Islamic beliefs and customs originating in shamanism, Buddhism, Manichaeism, Christianity and antique religions. ${ }^{4}$ In Anatolia, and later in the Balkans, Bektashism encountered further Neo-Platonist, Christian and Nestorian influences. Being receptive to many elements of these religions, the Bektashis also incorporated anthropomorphic and cabbalistic doctrines of letter and number symbolism that can be traced to Hurufism, 5 combined with an extremist Shiite credo that linked devotion to the divinity of Ali with beliefs in anthropomorphism, the manifestation of God in human form, reincarnation, and metempsychosis. 6

The Bektashis were one of the many bands of believers seeking to achieve the goal of most Sufis that is, a mystic union with God. When mystical union with God was not quite the goal sought, it was the cult of the miracle-working saints, living or dead, through worship of their tombs, which prevailed in the religious fervor of these heretic and heterodox groupings of dervish religiosity. Their function was to mediate the inner aspect of the religious experience. They were therefore integrated by spirit and aim rather than by any formal organization, and were in fact very loosely organized, more or less anarchical, closed, and secret groups or circles of initiates who showed no interest in sharing any collective discipline or dogma. Hadji Bektash himself, for instance, led the life of a wandering hermit and he did not seem to have been a prominent character in religious matters. He did not even seek to found any order or to have disciples during his lifetime. 7 He remained the eponym of an order he did not found himself, and was quite unconscious of the impact he was destined to have.

4. John K. Birge, The Bektashi Order of Dervishes (London: Luzac, 1937; reprint, 1994).

5. Irene Melikoff, Sur les traces du Soufisme turc: recherches sur l'Islam populaire en Anatolie, Analecta Isisiana 3 (Istanbul: Isis, 1992), 163-74; Alexandre Popovic and Gilles Veinstein, eds., Bektachiyya: études sur l'ordre mystique des Bektachis et les groupes relevant de Hadji Bektach (Istanbul: Isis, 1995), 39-53.

6. Irene Melikoff, Au banquet des Quarante: exploration au coeur du BektachismeAlevisme, Analecta Isisiana 50 (Istanbul: Isis, 2001), 97-120.

7. Melikoff, Hadji Bektach. 


\section{ARGUMENT}

Following innovative approaches regarding early Sufism in the eleventh and twelfth centuries, 8 Bektashism can be considered first as a reaction against the external rationalization of religion in law and systematic theology. Essentially, like other early Sufi groupings, in its earlier developments during the thirteenth and fourteenth centuries, Bektashism corresponded to the sphere of religious experience which developed from common experience of both spiritual knowledge and suffering, while running parallel and often in opposition to the orthodox institution and the mainstream of Islamic consciousness derived from prophetic revelation. Viewed in this light, the religious experience of the Bektashis presented conceivable characteristics of a liberation theology, while the structure of their groups corresponded more or less to the type of religious organization conventionally known as charismatic groups.

One of the functions of religion as a cultural system is to serve as a mediating representation between powerless earthly creatures and an all-powerful God located in heaven. Mediation would make it possible for the heavenly divinity to intercede on behalf of humans on earth. The assumption here is that different covenantal structures of divine mediation must correspond to specific stages in the development of Bektashism and Sufism. The following assumption is that it is possible to gain a different meaning if a mediating hierarchy is to be found in the conceptualization of the divinity or in the organization of the worldly human society.

Clearly, if there are mediators between humans and God, such as the Sufi and Bektashi master (murshid), for instance, or a priest or sacrificer, they act as representatives of the secular congregation and place themselves on a higher plane than the latter but in a position of inferiority with respect to the deity. However, the mediational structure may also be of another type, and claim to be the negation of hierarchy of any sort. The initiative must be entirely in the hands of the divinity, which may manifest itself in a number of hierarchized emanations but without any mediation, by dispensing the gifts of its grace on the faithful, with believers receiving direct, immediate inspiration. Charisma, divine grace, and spiritual knowledge touch them without the help of any intermediary, and is in no way affected by the more or less effectiveness of any ritual or specific expertise, performed or controlled by a mediating priest or master.

Following a structural hypothesis suggested by Edmund

8. J. Spencer Trimingham, The Sufi Orders in Islam (Oxford: Clarendon, 1971; reprint, 1998); Karamustafa, God's Unruly Friends. 
Leach,9 I have argued elsewhere that a crucial factor for understanding the communication between humans and God lies in the fact that the conceptualization of a hierarchical model of religious mediation corresponds to the dogma of orthodox faiths, while the conceptualization of a model in which all hierarchies are denied, in its real embodiments, is closely linked to millenarian and mystical beliefs and to the development of heresies and heterodoxies, ${ }^{10}$ such as those related to Bektashism. The former model may well support an established, hierarchical power, whereas the latter corresponds to an oppressed or deprived minority, seeking justification of its revolt against the established authorities.

According to this model, the establishment of a political hierarchy within society goes hand-in-hand with the introjection of a unified conception of divinity, that is, a pure monotheism within the theological system. On the other hand, a manifest hierarchical conception of the divinity goes along with egalitarian politics in human society. The conception of a relational equality, derived from the idea that people are equal in their relations with the divinity, is effectively present alongside an ideology of substantial egalitarianism among human beings.

One of the cornerstones of political anthropology is that ideology supports the existing power relations within the social community. Indeed, religious leaders are validated in many ways both by the overall Bektashi cosmology and by the myths which Bektashi masters themselves teach. Yet, both sociological conceptions of the role of religious faith, orthodoxy and liberation, are not, by any means, mutually exclusive or essentially contradictory. There are not two kinds of behavior set once and forever, nor is there a merely "routinization" in a Weberian sense, 11 but rather a process of dialectic change and transformation. As political conditions change and the organization of religious structures undergo a number of transformations, the final assumption is that the essential differences between hierarchical and unified types of theology, acting as mediating cultural systems of representation between humans and God, must change and adapt accordingly.

I showed elsewhere instrumental transformations of this kind

9. Edmund Leach, "Melchisedech and the Emperor: icons of subversion and orthodoxy," Proceedings of the Royal Anthropological Institute (1972).

10. Albert Doja, "Histoire et dialectique des idéologies et significations religieuses,"

European Legacy: Journal of the International Society for the Study of European Ideas 5, no. $5(2000)$.

11. Max Weber, Economy and Society: An Outline of Interpretive Sociology, ed. Guenther Roth and Claus Wittich, 2 vols. (Berkeley, Calif.: University of California Press, 1978), 24654. 
amongst the Bektashis in Albania from independent to postcommunist times. 12 It is my purpose to show here that similar transformations are clearly evidenced by the development of Bektashism down its history, depending on different political contexts and the course of events, as much in the classic Ottoman period, in the reformed Ottoman system or in Modern Turkey.

\section{TRIBAL POLITICS}

Before becoming the champions of Sunni Islam, the Ottomans, like all Turcoman tribes, passed necessarily through a period of assimilation of heterodox Islam, which corresponded with a period of social, political, and military crisis. According to Trimingham, the transformation of Sufi companionships into initiatory colleges began with the Sunni triumphs over Shiite dynasties, which coincided with the foundation of the Ottoman Empire.13 Bektashism will also find its final form at the beginning of the sixteenth century. It left its larval state to take the form which has since characterized it when efforts were made by Ottomans to organize the Order by making Hadji Bektash the patron of the Janissary body. This need had been dictated by disciplining the heterodox groupings and movements that were proliferating in Anatolia at this time in order to channel and bring them back under governmental control.

The last episodes of Hadji Bektash's Vilayet-Name are not only naive, but confused, seeking to gain the approval of the reigning dynasty and to attach to it the Turcoman popular saint which will become the eponym of the Order of Bektashis. F.W. Hasluck suggested that "Hadji Bektash," the reputed founder of the Order of Bektashis, and probably one of the most famous of the legendary priest-chiefs and tribal saints of Anatolia, was no more than a tribal ancestor, representing the original tribal-chief and medicine-man eponymous of his tribe. The whole legendcycle connecting him with the court of Orkhan is admittedly late, as the earliest notice of him which we possess from the fifteenthcentury Ottoman historian Ashik-Pasha-Zade denies its, authenticity and calls Hadji Bektash the "brother of Mentesh," which is obviously the eponym of a widely-scattered tribe encompassing Asia Minor. Bektashi is also a rarer, but widely scattered village name, and often, curiously enough, quite near villages called Mentesh. Hasluck inferred that "Bektash" and "Mentesh" were tribes which were related and that the original

12. Albert Doja, "A political history of Bektashism in Albania," Totalitarian Movements and Political Religions 7, no. 1 (2006).

13. Trimingham, The Sufi Orders in Islam, 67-104. 
Hadji Bektash was the eponymous ancestor of the former.14

To be sure, Hasluck's supposition of Bektashi as a simple tribal name was limited by the state of the knowledge in his time. Nonetheless, current research making large use of the historical data of Ottoman registers shows him correct. Moreover, a confrontation of data from tax registers to the legends reported in the Vilayet-Name of Hadji Bektash made it possible to confirm Hasluck's assumption that the order of Bektashi was born from the fusion of two tribal communities, namely the Bektashi and the Çepni.15 Hadji Bektash built his foundation on Çepni territory, which Irene Beldiceanu-Steinherr believes may indicate a takeover of Çepni territory by the Bektashi tribe. In her interpretation, it seems even probable that the antagonism opposing the Alevi circles to those that represent the vestiges of Bektashi brotherhoods could be explained by the frictions initially taking place between the two tribes.

According to Hasluck, Hadji Bektash might have acquired its reputation "by usurpation" and has nothing to do with the doctrines of the order which bears his name.16 Only his name was exploited later by the Hurufi-Bektashi sect and arbitrarily adopted by the Janissaries. The legend of Abdal Musa, the dervish who went together with the Sultan Orkhan (1326-1359) during his conquest of Bursa in 1326 and thereafter perpetuated the memory of Hadji Bektash by founding a first community of dervishes bearing his name, as all the subsequent legends concerning the foundation of the Janissary corps and its attachment to Hadji Bektash might have been nothing more than the "intrigues" of Bektashi leaders, aimed at appropriating the organization of Janissaries while the latter recognized Hadji Bektash as their patron saint and the Order of Bektashis as their spiritual ally.

In contrast with Hasluck, modern specialists, quite unusually given recent interests in political approaches, remain skeptical toward this interpretation. In repetitive studies, taking at face value the fanciful stories on the relationships between a number of personages reported in hagiographies and chronicles, the rationale to explain the first Ottomans' confidence is often claimed to be in the common social and ethnic Turkic origin they must have shared with the Bektashis. 17 Moreover, to consider the attachment of the name of Hadji Bektash to the Janissary body as

14. Frederick W. Hasluck, Christianity and Islam under the Sultans, 2 vols. (Oxford: Clarendon, 1929; reprint, Istanbul: Isis, 2000), 279.

15. Irene Beldiceanu-Steinherr, "Les Bektachis à la lumière des recensements ottomans (XVe-XVIe siècles)," Wiener Zeitschrift für die Kunde des Morgenlandes 81 (1991).

16. Hasluck, Christianity and Islam under the Sultans, 393-400.

17. Melikoff, Sur les traces du Soufisme turc, 115-37. 
a Bektashi "intrigue," the argument goes, is to seriously underestimate, at the time of heroic conquests, the importance of the Ottomans and the absolute power of their dynasty. 18

I believe, however, the problem is not so much underestimating Ottoman power, but rather to consider the conditions by which such common "intrigues" were made possible in the shared political interest of both the Bektashis and the Ottomans. Whereas the Bektashis became faithful tools of the central power, to the point of being assigned to Turkicize and Islamicize foreign and Christian elements, it is reasonable to see here the combination of a purposeful policy on the part of Ottoman sovereigns in a given historical context and the opportunity taken by the Bektashis, after they felt secure of governmental support, in order to maintain and extend their political benefit.

In Beldiceanu-Steinherr's interpretation, the Bektashis did not try to gain political power by placing their chances on the permanence of tribal structures, as did several other prominent tribes whose leading families were eliminated from the political arena by the victorious Ottomans. Rather, they placed their trust in spiritual power, in the long run transforming tribal organization and restructuring themselves as a dervish order.19 Perhaps another best-known case of such a transformation in anthropological literature is Evans-Pritchard's account on the Sanusi of Cyrenaica. They were able to coordinate the dervish system to the Bedouin tribal structure while maintaining the organization intact and keeping control of it. Thereafter, having risen up in opposition to Italian colonial domination, the Sanusi succeeded in achieving the evolution of their Order into the Kingdom of Libya. ${ }^{20}$

The Bektashis, seemingly a part of these wandering dervishes, gradually transformed into colonizing dervishes, whose main task became to convert recently conquered countries to Islam. This may also explain the rationale for appointing the order of Bektashis to guide and patronize the Janissaries, as they were recruited from among the Christian children converted to Islam and raised in Turkish circles. Already in the fifteenth century, this order of dervishes was protected by the Ottoman dynasty, having been granted a significant endowment.21 Apart from personal piety or the desire to strengthen the Ottoman dynasty

18. Melikoff, Hadji Bektach, 93.

19. Beldiceanu-Steinherr, "Les Bektachis à la lumière des recensements ottomans."

20. Edward E. Evans-Pritchard, The Sanusi of Cyrenaica (Oxford: Clarendon, 1949).

21. Suraiya Faroghi, Der Bektaschi-Orden in Anatolien: vom späten fünfzehnten Jahrhundert bis 1826 (Wien: Verlag des Institutes für Orientalistik der Universität Wien, 1981); Beldiceanu-Steinherr, "Les Bektachis à la lumière des recensements ottomans." 
through the prayers of dervishes on a supernatural level, on a more mundane plane, these donations must have been motivated by the wish to both attract and recompense the loyalties of pious subjects, in order to knit them more closely into the Ottoman fabric.

This explains why the Bektashis were increasingly on the point of being considered, paradoxically perhaps, given their heterodox inclination, as the state religious order. The Bektashis were in fact very unorthodox and had gained such a strong reverence for the house of Ali that it might well be called a Shiite order. However, since the Ottomans tolerated both Sunni legalism and institutional Sufism but forbade all varieties of Shiism, the Bektashis were a self-proclaimed Sunni movement.

\section{The POLITICS OF SYNCRETISM}

A general claim is that the Bektashis preserved many traits of oppositional movements and heretic groups, and shaped them into a synthesis during times of a mutual penetration of Turkic and Byzantine cultural traits. There is clear evidence for the participation of Hadji Bektash himself and his adherents in the Turcoman uprisings against Seljuk rule in 1239-1240, the socalled Babaî revolt. 22 However, there remains probably very little resemblance between the Turkic beliefs of Hadji Bektash's time in the thirteenth century and those that formed the heterodox but sophisticated doctrines at the turn of the sixteenth century when the Bektashis were organized as an established Order of dervishes.

The considerable number of doctrines and practices supposed to lay at the heterogeneous origins of Bektashism has lead to heated disputes between specialists over the prevalence of one or another influence and finally to claim that the Bektashi Order did not have a well defined theology, that it could accommodate much local influence, and that its fundamental character is an allencompassing syncretism.23 In its complexity, many have considered Bektashism as a "syncretistic problem," a kind of "kaleidoscope," each time revealing one or another facet which escapes attention. 24 After many times taking up and resuming the same work, the Bektashis came to be considered as simple "victims" of their colonizing and civilizing role, ${ }^{25}$ which must have transformed them into an overtly heterodox order allowing

22. Mehmed Fuad Koprulu, Islam in Anatolia after the Turkish Invasion, ed. Gary Leiser (Salt Lake City, Utah: University of Utah Press, 1993), 76-77.

23. Melikoff, Sur les traces du Soufisme turc; Popovic and Veinstein, eds., Bektachiyya.

24. Melikoff, Hadji Bektach, 278.

25. Melikoff, Sur les traces du Soufisme turc, 125. 
the infiltration of foreign heretic influences.

Although Bektashism had spread over a wide area and gained many adherents, it is considered that "before 1500 both the order and its teachings developed in a random fashion." In addition, specialists are led to consider that "this vagueness of belief was paralleled by lack of uniformity in their organization," even though they normally attribute this character to the supposed Bektashi all-encompassing syncretism and "readiness to incorporate a wide range of beliefs and practices, which made it difficult to define precisely what the order stood for." 26

Other specialists have also many times recorded and described the facts without explaining them. More generally, some probably lack an analytical and explanatory approach to socio-religious and Islamic matters, which is necessary in order to expose whether or not an instrumental politics of religion is hidden behind the surface complexity of Bektashism. It can be argued, indeed, that behind the "syncretistic" elements of Bektashism we can look for indications of the political and military rivalries between the Ottomans and the Safavids fought in the domains of religion and ideology.

While the complexities of the Bektashi past may never be known precisely, it appears that historians agree that they were often tribal or nomadic communities who inhabited that uneasy geographical region between the central power of the Ottomans, on the one hand, and the gradually more orthodox Safavid Iran on the other.27 While they were exposed to many different currents of Islamic thought, one of the most effective was a form of revolutionary mysticalleadership espoused by Iranian Shiism.

However, indirect evidence from Ottoman sources, such as the analysis of individual names recorded in tax registers, 28 seems to confirm the commonly agreed opinion that Bektashis did not adhere to Shiite tenets before 1501. The massive intrusion of Shiism is a late phenomenon, contemporary with the Ottoman conquest, and a coherent corpus of Shiite doctrine was never composed or diffused before in Anatolia, 29 even if some evidence of its propagation can be found from the thirteenth century onward.

26. John D. Norton, "The Bektashi in the Balkans," in Religious Quest and National Identity in the Balkans, ed. Celia Hawkesworth, Muriel Heppell, and Harry T. Norris (New York: Palgrave, 2001), 171.

27. Krisztina Kehl-Bodrogi, Die Kizilbash/Aleviten: Untersuchungen uber eine esoterische Glaubensgemeinschaft in Anatolien, Islamkundliche Untersuchungen, 126 (Berlin: Klaus Schwarz Verlag, 1988), 42-47.

28. Beldiceanu-Steinherr, "Les Bektachis à la lumière des recensements ottomans."

29. Claude Cahen, Pre-Ottoman Turkey: A General Survey of Material and Spiritual Culture and History (London: Sidwick \& Jackson, 1968). 
Heterodox beliefs proliferated in all segments of the population, in the towns as in the countryside, and all religious tendencies mixed together, from the most moderate to the most heretical. A large veneration for Ali more or less penetrated all the Sunnite religious milieus, but adherence to Shiism or to Sunnism was a question which the contemporaries may not have asked. Over several centuries, heterodox groups grew at the expense of orthodox Sunni and Shiite Islam, and only during the sixteenth century did the Ottoman and Safavid authorities start to impose anything like a state religion on the local population. Everything suggests that the massive diffusion of Shiism is precisely linked to the modalities of antagonistic relations between the Ottomans and the Safavids following the Ottoman conquest, as well as to the segmentary nature of Turcoman tribal society in conflict with Ottoman centralism from the early period of the conquest.

Ottoman historiography has tried to dissimulate the existence of a plurality of competitive political and ideological forces, but it seems that tribal rivalries divided the Turkic populations of Anatolia from the beginning of the Ottoman conquest. There were, on the one hand, the partisans of the Ottoman House and, on the other, hybrid warrior-dervish figures (Ghazi), mobilized by one or another factions, of whom one finds traces in sources as diverse as census registers to Ottoman and Byzantine chronicles and hagiographical legends. In particular, the name of Kizilbash appeared for the partisans of the Safavids. This anarchistic movement, whose majority was formed by the Turcoman tribes coming from eastern Anatolia, was transformed into a politicoreligious force which the Safavids made an instrument of their policy, at the origin of their spectacular rise, their defeats and their victories, up to the apogee of their political and religious organization, the crowning in 1501 of the young Shah Ismail (1487-1524), the restoration of the unity of modern Persia, and the imposition of Twelver Shiism as a state religion. 30

Thus, the relative crystallization of the religious practices of rural Anatolia into a corpus of Shiite representations became probably a reality only after the advent of the Safavid dynasty in Iran and from the struggle between these two competing Turcoman dynasties, that of the Ottomans who became the champions of orthodox Sunni Islam and that of the Safavids who instituted Shiism as a state religion in Iran. The inexorable extension of Anatolian Shiism and its identification with political resistance, becoming a rallying sign of those fighting against the central authority of the Ottoman State, seems to have had a

30. Adel Allouche, The Origins and Development of the Ottoman-Safavid Conflicts (906962/1500-1555), Islamkundliche Untersuchungen, 91 (Berlin: Klaus Schwarz, 1983). 
starting point. ${ }^{31}$ A direct relationship could be drawn with the attraction exerted by the Safavid power to the nomads in Eastern Anatolia, coming up against the Sunni Ottomans pressure of centralization, and with the defeat of Shah Ismail at the battle of Kaldiran in 1514, followed by the massacre of several thousands of Anatolian Kizilbash, whose remembrance remains still alive in the memory of the Bektashis-Alevis.

Many of the Anatolian Kizilbash maintained occasional connections with Iran throughout the sixteenth century. The Shah of Iran acted as the leader of a Sufi order, sending books, insignia and emissaries who often appointed representatives (halife) from among the Shah's local adherents. To these attempts, the Ottoman administration reacted ferociously. Even in peacetime, Iranian envoys were often enough set upon and provincial governors were instructed by the authorities in Istanbul to make these attacks look like ordinary robberies. ${ }^{32}$ As to the Anatolian "contact persons" of the Iranian emissaries, they were often executed unless they could flee into the protection of certain powerful tribes who continued to form a bastion of Anatolian heterodoxy.

The ideological basis of the Iranian dynasty was rooted in the extremist Shiism drawn from those Kizilbash elements which would subsequently become the essential constituent parts of Bektashism. From this period onward, the expanding Ottoman Empire tended to consider the Shiites within its territories as fifth columnists and persecuted them accordingly. With the advent of Selim I (1512-1520) there is no further record of gifts to Bektashi foundations until the eighteenth century, and according to a Bektashi tradition the central foundation of Hadji Bektash was closed at this time and would reopen only in 1551 . This act would prove that the Sultan did not consider the Bektashi innocent. The records in Ottoman sources show that for most of the sixteenth century there is some reason to assume that the Bektashi community at least suffered temporary losses. ${ }^{33}$ In fact, the contact with nomadic tribes continued after this period, as shown by the fact that the central foundation participated, at least indirectly, in a series of rebellions and uprisings.

In this context, Anatolian Shiism appears more as the political

31. Altan Gokalp, Têtes rouges et bouches noires: une confrérie tribale de l'Ouest anatolien (Paris: Société d'Ethnographie, 1980), 72-73.

32. Suraiya Faroqhi, "Conflict, Accommodation and Long-term Survival: The Bektashi Order and the Ottoman State (sixteenth-seventeenth centuries)," in Bektachiyya: études sur l'ordre mystique des Bektachis et les groupes relevant de Hadji Bektach, ed. Alexandre Popovic and Gilles Veinstein (Istanbul: Isis, 1995), 173.

33. Suraiya Faroqhi, "The Tekke of Hadji Bektash: social position and economic activities," International Journal of Middle East Studies 7, no. 2 (1976). 
expression of nomadic Turkoman tribes than as one of the manifestations of medieval Muslim mysticism. The few socioanthropological analyses have showed that Kizilbash-Alevi heterodoxy can be perceived as the transposition into a religious form of the resistance of Turcoman chieftaincies to the Ottoman state. Using the concept of a "society against the State" proposed by Pierre Clastres, 34 Altan Gokalp showed in his in-depth analysis of the Kizilbash system that the Shiite component of Bektashism and of the Anatolian Turcoman appears to be the result of the very structure of their social organization defined by complementary tribal, territorial, and political relationships, whose structural relativity and segmentation in different levels lead to particular arrangements adapted to the circumstances. ${ }^{35}$ Thus, in Gokalp's interpretation, "the conjunction of Shiism and nomad society in Anatolia appears to be the result of the harmony existing between the principles of social organization inherent in a clan structure and those in a brotherhood. 36

In this sense, the structure and functioning of the Bektashi religious system demonstrate a remarkable continuity. In face of the powerful Ottomans, the Bektashis transformed their tribal organization and restructured themselves as a dervish order. Thereafter, in contrast to the monolithic nature of Sunnite Islam which integrated Muslim society within a political and economic system where the ulema clergy were part of the state apparatus, the Bektashi integrated Kizilbash ideology within a segmented structure mirroring once again their tribal system of social organization. In short, the Bektashi religious system appears as a prime means of thinking out the social life and political struggle of those excluded from Ottoman polity and society.

To this extent, if the Ottoman Sultans, beginning with the reign of Selim I, launched forth to persecute heterodox Shiite elements, it was not because they had suddenly discovered their vocation as defenders of orthodox Sunnite Islam but rather because they saw in these elements a danger to the political and economic integrity of the empire. 37 By the same token, it is necessary to reject the classical interpretations by specialists who present Bektashism in terms of a dynamic syncretism, which first integrated the remnants of Anatolian Christianity and Central Asian shamanism, and which has thereby allowed its followers to integrate certain symbols and meanings from different religious

34. Pierre Clastres, La Société contre l'État (Paris: Minuit, 1974).

35. Gokalp, Têtes Rouges et Bouches Noires.

36. Altan Gokalp, "Une minorité chiite en Anatolie: les Alevis," Les Annales: Histoire, Sciences Sociales 35, no. 3-4 (1980): 756-57.

37. Irene Beldiceanu-Steinherr, "Le règne de Selim I: tournant dans la vie politique et religieuse de l'Empire ottoman," Turcica 6 (1975). 
systems, above all including, the argument goes, Shiite representations.

The saga of repression in the Safavid period became part of a broader symbolic framework, inherent to Shiism, which is itself founded on an original tragedy, capable of giving free expression to the oppressed, prior to a possible mobilization. In the case of the Kizilbash, the identification of their social condition with the Shiite martyrdom was encouraged by the fact that the Prince whom they recognized, Shah Ismail, defeated at Kaldiran, was also a great Turkish-speaking mystic poet and a follower of Shiism. To stimulate the warring fervor and religious commitment of his partisans, he used poems in syllabic verses written in the popular Turkish language. In these elegies, which made him one of the most famous poets of the mystical literature in Turkish language, he proclaimed himself to be the most humble of "sinners," hence his surname of Hatayi, and he drew upon the existence of mystic extremist Shiism and messianic Turkic beliefs in the manifestation of God in human form (tecelli), in reincarnation and the multiplicity of forms (tenassuh).

He declared himself to be the divine essence, the manifestation of God (mazhar) and the cyclic incarnation of Ali, of whom he was the Mystery. In the cycle of universal rotation, he was the incarnation of the prophets and the great mystics. All owed to prostrate before him, the one to be adored like a God. In Kizilbash ideology, the divine manifestation was indeed incarnated in the Safavid sovereign, adored and deified by his partisans, and the invocation of the temporal shah became a manifestation of the spiritual shah. Shah Ismail tended thereby to be assimilated to Ali, the eternal god of heaven manifested on earth as the "king of men" (shah-i merdan), 38 and he proclaimed himself as envoy of God (Mehdi) to save the Anatolian Turcoman from the hand of the Yezid, that is, the Ottomans. The followers, in that way fanaticized and carried away by a blind faith in their young Shah, proclaimed his divine character, prostrated themselves before him in prayers, and threw themselves into battle with abandon.

It is thus not surprising that some Turkish historians have gone so far as to consider Shah Ismail as the real creator of Kizilbash-Alevi heterodoxy. "If he had not existed, it is argued, there would certainly have been an Islamo-Turkish heterodoxy, but there would not have been Kizilbashism."39 Indeed, the

38. Melikoff, Au banquet des Quarante, 87-118.

39. Ahmet Yashar Ocak, "Un aperçu général sur l'hétérodoxie musulmane en Turquie: réflexions sur les origines et les caractéristiques du Kizilbachisme (Alevisme) dans la perspective de l'histoire," in Syncretistic Religious Communities in the Near East, ed. Krisztina Kehl-Bodrogi, Barbara Kellner-Heinkele, and Anke Otter-Beaujean, Numen 
messianic beliefs strengthened by Shah Ismail seem to have been a decisive turning point in the evolution of Bektashism. Certain rituals still practiced today owe their renewed and reformed patterns to Shah Ismail. Among other things, he supposedly established the specific sequence of the most important moment of the Bektashi ceremony, the proclamation of divine unity (tewhid), which becomes, in reality, the assertion of the identity of Ali and Divinity.

The dissimulated presence of Shah Ismail, perceptible thanks to the Hatayi canticles sung during the ceremony, allowed specialists to assume that the structure of the ceremony definitively crystallized during his epoch.40 Shah Ismail is still considered today as the master of Alevi poetry, which progressively crystallized from the sixteenth century onward into a real tradition around the themes of resistance, persecution, and martyrdom. Hatayi elegies are always sung during the religious ceremonies of the Bektashis and continue to move enthusiasm in the assemblies of Alevi villages.

To this extent, the necessity for the Ottoman authorities to bring back under governmental control the tribal religious system of Kizilbash groups becomes more understandable. Around the turn of the sixteenth century, it appeared natural and necessary further to reform and reorganize the Order of Bektashis, and the reform was to effectively be accomplished by the explicit sovereign will of the Ottoman power. Once again according to the legend, in the early sixteenth century, Sultan Bayezid II (1481-1512) invited Balim Sultan, the Bektashi leader at the time, to be his guest, and the Sultan himself with high officials of the court joined the Bektashi order.41

In plain words, as Birge pointed out, 42 it was the Ottoman Sultan who appointed Balim Sultan precisely in 1501 to the headship of the Seat of the Patron Saint (Pir-Evi) at Hacibektash Village. In return, the Sultan should have expected the dervishes to wean the tribesmen away from the mixture of folk Islam and Shiite beliefs which they had espoused until that time. Bayezid II, who was known for his generous donations to many pious institutions and in spite of his supposedly passive policy, must have been certainly seeking to counterbalance the subversive elements which came from the Iranian frontier and which intensified due to the increasing propaganda of the Safavids, whose partisans mainly came from the Turcoman tribes. After all, the foundation of the Safavid state in Iran and the

Studies in the History of Religions 76 (Leiden: Brill, 1997): 199.

40. Melikoff, Hadji Bektach, 195.

41. Melikoff, Sur les traces du Soufisme turc, 29-43.

42. Birge, The Bektashi Order of Dervishes, 57. 
uprisings in southwestern Anatolia had shown that tribal heterodoxy could threaten Ottoman control.

In turn, it is certainly not accidental that the new emblematic personage appointed at the headship of the Bektashis will be the great reformer and organizer of the Order. Considered as the second major leader in the history of Bektashism, often called the "second patron saint" (Pir-i Sani), Balim Sultan made determined efforts to reform its organization and the practice of its members, apparently because both of which had succumbed to unorthodox practices and rituals. In accordance with the will of the Ottoman sultan, Balim Sultan took in hand the anarchic group of the dervishes, and he transformed them into an organized order.

Some of the innovations, still believed to have been introduced directly under the influence of this new leader, provided permanent form and content to the system of beliefs and practices of the order in terms of doctrine, ritual and organization. Thanks to this reformer, the Order, essentially scattered in village foundations, not only would come closer to urban settings, but would gain a permanent organizational structure, directed from above by a centralized hierarchy and characterized by well-defined rituals and religious functions. This organization became the more formally organized Bektashi Order, as in some measure distinct from the Alevi village groups who continued their very similar beliefs and practices, but outside the regulated system of Bektashism, which from that time onwards started to enjoy state political patronage.

\section{STATE POLITICS}

The period between 1560 and 1585 provides ample information on proceedings against individuals or communities accused of heterodoxy. However, they contain no information on persecutions directed at the dervishes of well-known Bektashi communities. This fact makes it seem likely that the major Bektashi foundations were not among the main targets of official repression. On the other hand, other communities in Central Anatolia that were in serious difficulty, along with many "various groups which would have been regarded as schismatic and liable to be persecuted in the type of Sunni state towards which the Ottomans was moving, gained the right of asylum under the all embracing and tolerant umbrella of the Bektashi organization." 43

The persecution of Anatolian Kizilbash apparently died down after the 1580s, even though the Ottoman-Iranian wars went on

43. Trimingham, The Sufi Orders in Islam, 83. 
intermittently until the treaty of 1639 . It has been suggested that this change in Ottoman policy was due to the reorganization of Safavid public administration. After the military Iranian reforms at the end of the sixteenth century and when the Twelver Shiite persuasion progressively gained influence in Iran, either the attractiveness of Safavid Iran for the heterodox tribesmen decreased dramatically, 44 or the Shah of Iran was no longer interested in exercising influence as a Sufi master in Anatolia.45 Thus, when tribesmen could no longer expect an assured position in the Safavid military establishment, their loyalty to the Iranian dynasty must have suffered proportionally.

In the short run, however, according to Suraiya Faroqui, a change in Iranian tactics was not the reason for the softening of official attitudes toward the Anatolian Kizilbash, especially as the rebellions taking place all over Anatolia during those years may have induced the Ottoman administration to revise its own policies. After all, the Kizilbash uprisings of the earlier part of the century were succeeded almost without interruption by the uprisings of the years between 1580 and 1620, thus the danger from Kizilbash-inspired movements probably having not totally disappeared.

As for the aim of this change in internal policy, one might consider the assimilation of the remaining Anatolian Kizilbash, by isolating the leaders from their political constituency and, of course, by eliminating as far as possible all connections with Iran. In this context, it should have made sense to revive the policy of using the widespread popularity of the dervish order of Bektashis to neutralize the Kizilbash as a political force. The Bektashis probably already possessed a certain prestige among the Kizilbash, but it is of course not necessary to see here, as usually specialists do, an essential affinity between Bektashism and oppositional movements. The observation concerning the inclination of many heterodox dervishes to affiliate with the Bektashi order must take on a new meaning. Not only did these people try to avoid persecution by joining the Bektashi order, which already under Bayezid II (1481-1512) had shown its capacity to Islamicize nomads, but in Suraiya Faroqhi's interpretation, the Ottoman administration must have tolerated this move and even encouraged the Bektashi order to exercise its powers as an agent of assimilation and acculturation. 46

One might object that in one way or another, a number of

44. Kehl-Bodrogi, Die Kizilbash/Aleviten.

45. Hans R. Roemer, "Die turkmenischen Kizilbash: Gründer und Opfer der Safawidischen Theokratie," Zeitschrift der Deutschen Morgenländischen Gesellschaft 135, no. 2 (1985).

46. Faroqhi, "Conflict, accommodation and long-term survival," 177. 
people associated with the Bektashi order had shown heterodox leanings and that, as a result, the order as a whole should have seemed suspect to the central authorities. As a matter of fact, in order to communicate with their flock, the Bektashi missionaries had to adapt to the culture of the tribesmen, and as a result were assimilated to the heterodox milieu they had been set out to change. After all, it is only in these circumstances, after having integrated many of the escapees from the repression of popular heresy in Anatolia at the time of the Ottoman-Iranian wars, that the Bektashi order gained its identity as an order of doubtful religious orthodoxy.

The danger that the extremist Kizilbash may "take over" the Bektashi organization must have been apparent to both the Ottoman government and the Bektashi leaders. Under these conditions, the policy of assimilating the Kizilbash and allowing the Bektashi order to legitimize Ottoman rule toward these Anatolian heretics could only make sense if the leaders of the Bektashi order were allowed some means of control over the people entering their organization. Namely, the head of the central foundation of Hadji Bektash possessed such a degree of control in that he was allowed to have some say in the appointment and supervision of leaders in charge of all other foundations claiming allegiance to the order. Indeed, he very much insisted that his right to present candidates be respected, and the Ottoman administration kept on confirming this privilege even after its raison d'être had vanished, according to a procedure which was to become routine throughout the seventeenth and eighteenth centuries. 47

In Faroqhi's interpretation, it becomes possible to link the cessation or at least the toning down of anti-Kizilbash persecution in the later sixteenth century and the official grant of privileges to the head of the central Bektashi foundation. But this also suggests that the prerogatives of the head of the central foundation of Hadji Bektash were not only meant to control the process by which Anatolian Kizilbashs were being absorbed into the Bektashi order. More importantly, the whole thing might have been intended to facilitate central control from the Ottoman administration over the Bektashi order.

Certainly the powers of the order's head were limited by the fact that almost all foundations were governed by families in

47. The first document of this kind was issued by Ahmed I (1603-1617), in a rescript of 1610 that asserted the right of the incumbents of the central foundation to be consulted in the appointment process of all Bektashi leaders throughout the Ottoman Empire. As the text itself indicates, the head of the Bektashi order had actually exercised this privilege at an earlier date, and only intervention on the part of the local state official had prompted him to seek official confirmation of his prerogatives. Ibid. 
which this dignity was still hereditary. 48 But if Suraiya Faroqhi is correct, her interpretation could be merely supported by the fact that usually there was more than one heir to choose from, which allowed the head of the central foundation to eliminate those candidates that in his opinion might compromise the order as a whole. I rather believe such a policy would only make sense if the Bektashi order were itself reorganized along non-hereditary offices, and we probably must look here for the rationale of later developments in that direction.

From the early sixteenth century, the Bektashi order consisted of two branches. One was associated with the presumed descendants of Hadji Bektash who controlled the estate of the order's main foundation, and the other consisted of unmarried leaders who claimed institution by the order's "second founder," Balim Sultan.49 Certainly, tax registers could only show that the Ottoman administration concerned itself almost exclusively with the hereditary leaders of the foundation and all but completely ignored the unmarried ones. But we know that it is precisely this "second founder," by the Ottoman Sultan appointed, that took over the Bektashi order and paved the way of its further hierarchical organization along the lines of normative practices and, not surprisingly, non-hereditary offices as well.

Possibly the control which the leaders of the central Bektashi foundation exercised over the lodges belonging to their order was simply a special instance of a more general kind of control, which encompassed all persons claiming affiliation with the Bektashis. Even today Alevi groups and villages may propose the names of their spiritual elders to the leaders who once controlled the main Bektashi foundation.50 This activity was important enough to provide the leaders of the Bektashi order with an important ritual function throughout the decades during which the order has been officially prohibited. This would perhaps explain why the Bektashi leaders were regarded not only with less suspicion than the marginalized Alevis, but more importantly they held a respected position and were even considered local-level dignitaries in mainstream Ottoman society.

\section{POLITICAL REVERSAL}

By their very existence, the Bektashi order of dervishes became a powerful factor for the state to reckon with, since they continued their activities even in those periods which did not

48. Faroqhi, Der Bektaschi-Orden in Anatolien, 79.

49. Birge, The Bektashi Order of Dervishes, 56-58.

50. Kehl-Bodrogi, Die Kizilbash/Aleviten, 47. 
offer any immediate provocation as to the use of force. Throughout Ottoman history, they have exercised a considerable, albeit ill-defined, influence over certain sections of the population. At some periods, for instance, at the end of the sixteenth century, political and other combinations have enhanced this influence to such an extent as to make them potentially important allies or dangerous enemies to the civil government. During this period, the Bektashi dervish order set their ascendancy by making official their connexion with the Janissaries. This official connection, backed by the sanction of the superstitious classes of the population, made the JanissaryBektashi combination a very dangerous one during the succeeding period of weak monarchs and decadent national morality, and it continued to embarrass the Ottoman government until the abolition of the Janissaries and the fall of the Bektashi in 1826.

Recrudescent troubles with the Janissaries were one of the chief internal causes of the decay of the Ottoman power in the seventeenth and eighteenth centuries. Sultans like Osman II (1618-1622) and Ibrahim (1640-1648) made vain efforts to curtail their power only to become their victims. Only in the third quarter of the seventeenth century, an interlude of national revival allowed the last important extension of the Ottoman Empire. The cause of this revival laid not in the ability of the sultan Mehmed IV (1648-1687), but in that of his viziers of the Koprulu family. They attempted to make a stand against the power of the Janissaries in politics and against the prevalence of heterodoxy in religion, much of it due to dervish influence which threatened to undermine both orthodox faith and Ottoman authority.

Called to office in 1656 for the express purpose of quelling an unusually dangerous rebellion of the fanissaries, the elder Koprulu executed four thousand persons implicated in the movement, including several influential dervishes; his influence was felt throughout the empire until his death. The action against the dervish orders strengthened more than ever in the vizierate of his son, who followed his father's policy. The religious counterpart of political measures appeared with some persuasive preachers of the strictest Sunni principles, who obtained a great influence over the orthodox Sultan. Strong efforts to abolish the public exercises of the dervishes in general, and to stamp out the mystic Sufi doctrines professed by many members of the upper classes and the cult of saints and other superstitions in vogue among the lower, were typical of the general policy of the Koprulu viziers. 51

51. Hasluck, Christianity and Islam under the Sultans, 348-50. 
Although current knowledge is very limited, it also seems that pitting one dervish order against the other was occasionally tried. The whole of a cycle of fictitious legend composed in relation to the coveted ceremony of the girding of the sword at the accession of the Ottoman sultans to the throne and the connexion of the ceremony with the Seljuk sultans of Rum were evidently devised to increase the prestige of the Ottoman house in Anatolia. At the same time, the fabrication of all legends alike seem nonetheless aetiological intentions designed to increase the prestige of the orders concerned and sometimes to pave their way to a new political claim. The traditional privilege of the Mevlevi Sheikh to play the chief part in the investiture of the Sultan, by girding the new sultan with the so-called sword of Osman, was calculated to enhance the prestige of the Mevlevi order and eventually to keep the balance with the Bektashis and their influence upon the military.

In his analysis of the history of the ceremony, F.W. Hasluck insisted on a political combination of the sultan with the Mevlevi order against the Janissaries and their allies the Bektashi dervishes.52 The privilege of the Mevlevi Sheikh, even though traditionally performed for the first time as far back as 1648 at the accession of Mehmed IV to the throne, seems to be not an ancient institution but a comparatively recent innovation, and that there is a good deal of evidence to show that it became regular only after the accession of Mahmud II in 1808. Preeminently a reforming sultan who continued the policy of Selim III (1789-1807), Mahmud II (1808-1839) aimed to remodel the army, which involved the abolition of the Janissaries who were backed by the dervish organization of the Bektashi. By the drastic action of 1826, the sultan rid himself of the Janissaries and paralyzed the Bektashi organization, while enlisting the Mevlevi as his allies.

Characteristically, the fate of the conniving relationship between the Bektashis and Ottoman power after 1826, when the order was suppressed, is normally attributed to the link with the Janissaries who were dissolved in that year, causing the fall of the Order, as it were, involved in their disgrace. Some Bektashi leaders were executed, and many of the order's properties were destroyed. There were widespread deportations and forced resettlements of the order's members and sympathizers. Nakshbendi sheikhs were appointed to oversee and control some of the Bektashi foundations that were spared. Others were turned over to the ulema for use as mosques, religious schools, caravansaries, hospitals, and the like. Various Bektashi functions among the military were transferred to the Mevlevi. Other

52. Ibid., 483-95. 
functions related to public life were transferred to the Nakshbendi.

It is unlikely, however, that material considerations were the cause of the Ottoman central administration's closing of the Bektashi foundations in 1826. Even 'allowing for the possibility that Ottoman fiscal officials vastly overestimated the Order's resources, other motives must have been decisive. The affiliation of the Bektashis with the Janissaries, which apart from the heretical beliefs of the Bektashi, formed the official reason for the campaign of repression, was probably not the main reason either. After all, the order's main strength lay in small and medium-sized towns where the Janissary connection was of marginal importance. More decisive, as Suraiya Faroqhi has suggested, 53 was the attempt to use the drastic measures as a sort of trial balloon in order to placate the Ottoman religious system as a whole at a time when the control of ulema over pious foundations was being eroded by the state. As the ulema did not protest against this wholesale confiscation of legally constituted pious foundations, measures of this kind were not politically dangerous to the Ottoman government and could soon be repeated on a larger scale.

However, in the aftermath of the official banning of the order of Bektashis following the abolition of the Janissary army, while the latter were permanently broken, Bektashism was not annihilated, but only crippled and resumed a more or less underground existence, sometimes masking their identity through other orders. By the middle of the nineteenth century, they had largely recovered, and in the late nineteenth and early twentieth centuries, the order even entered a period of renewed popularity. The Bektashis started again to exercise a considerable influence over the laymen affiliated to them, which only strengthened their heterodox and non-conformist cleavage. Once reduced to a clandestine life, they gradually drew closer to the Freemasons, with whom many upper-class Bektashis shared a common ground of liberalism, non-conformism, and anticlericalism. In that way, the Bektashis came to play the role of an enlightened intelligentsia, open to progressive ideas. Coming from the intellectual and liberal elite, they are said to have played in the Ottoman Empire a role similar to that of Freemasonry in the European reformist movements.

If the Bektashis succeeded to have an influence in the reformed Ottoman context after 1839, this was made possible thanks to their affiliation to the Franc-masonry and their alliance with the Young-Turks. Many were indeed among the prominent

53. Faroqhi, Der Bektaschi-Orden in Anatolien, 115-19. 
personalities of the time who were at once Bektashis, Freemasons, and Young-Turks.54 This made it possible for Bektashism to form links with certain members of the Ottoman elite and find support from influential people both in the palace and the state administration. It is true that between 1869-1876 there was an unprecedented burst of open Bektashi publicity which would never have been allowed unless they were receiving protection in high places of authority. The claim is made, for instance, that the Vilayet-Name was published in 1871 under the secret protection of the mother of Sultan, and that other Bektashi books were printed at her expense. 55 It seems that many in the close entourage of the Sultan Abdul-Aziz (1861-1876) were adherents or sympathizers of the Order of Bektashis. The reign of Abdul-Hamid II (1876-1909), in particular, is seen as a period in which an exceptional relationship was established between the government and the dervishes, who enjoyed a veritable boom.

In turn, the connection with enlightened and influential intellectuals involved in active political life made it possible and necessary for the Order once again to reorganize itself. Apparently, it was a sympathizer of Voltaire's ideas, Fazil Bey, who is said to have reorganized the order by introducing freethinker and freemason ideas, 56 which made of the Bektashis one of the driving elements of the Young-Turk movement. The large use of Bektashi and later Alevi culture, in particular, proved to be highly instrumental for backing Young-Turk reformist ideology in its emphasis of the breakdown of the cultural cleavage that separated the Ottoman elites from the majority common people by looking back to Turkic origins. Increasing attempts were made to interest Bektashi leaders and other dervish orders in the modern state and use their assistance in formulating a cultural program, 57 which would later give rise to Turkish nationalism.

Something similar must have been in the mind of Ataturk, who did even pay a visit to the central Bektashi foundation in December 1919, trying to get the Bektashis-Alevis as allies. In fact, the head of the Bektashi order sided with Mustafa Kemal, and published a letter instructing his followers to support the nationalist forces. This effort, however, did not result in any exceptional favours to the Bektashis, since after some time Ataturk turned away and finally all dervish orders were abolished

54. Melikoff, Hadji Bektach, 243-44.

55. Birge, The Bektashi Order of Dervishes, 80-81.

56. Melikoff, Sur les traces du Soufisme turc, 77.

57. Hans-Joachim Kissling, "The Sociological and Educational Role of Dervish Orders in the Ottoman Empire," in Studies in Islamic Cultural History, ed. Gustave E. Grunebaum, Memoirs of the American Anthropological Association 76 (1954): 35. 
by the Republican government in 1925 .

\section{ReVIVAL Politics}

In a very broad generalization, it has been argued a "historical bipartition" between the Bektashis who were traditionally urbanized and educated and the Alevis who lived in villages, the former having spread in the Balkans and the latter remaining in the Anatolian countryside.58 Bektashism is therefore often considered as a kind of "purified" Islam, what an older generation of social anthropologists might have termed the "great tradition" of the urban and organized Bektashi Order against the "little tradition" of the rural and less-educated Alevi or Kizilbash. To show, however, that modern Alevi and Bektashi groups have much more in common than they have differences, the Alevis themselves will often talk about "Alevi-Bektashi" creed, culture, or traditions.

In the persecution climate during the Ottoman-Safavid wars in the sixteenth century, the isolated Kizilbash-Alevis in rural Anatolia developed traditions, practices, and doctrines that by the early seventeenth century marked them as closed, autonomous religious communities, opposed to all forms of external religion.59 Alevism formally was, and to some extent still continues to be, a social stigma in contemporary Turkey, and many Alevis have attempted to hide their backgrounds once they moved to large cities.

The relationship with the Sunni majority remains one of mutual suspicion and prejudice, dating back to the Ottoman period. Sunnis have accused Alevis of heresy, heterodoxy, rebellion, betrayal, and immorality. Alevis, on the other hand, view themselves as the true preservers of authentic Turkish culture, religion, and language. Alevism is claimed to adapt to modernity because it is supposed to be flexible and tolerant, out of a natural sense of equality and justice. It is much more suitable for it includes traits supposedly suppressed by Sunnism, which would thereby not be true Islam but an aberration that opposes free and independent thought by its strict legalism, seen as reactionary, bigoted, fanatic, intolerant, domineering, and antidemocratic.

The last three decades have witnessed in contemporary Turkey what has come to be known as an Alevi cultural revival, leading to issues of Bektashi or Alevi heterodoxy being heatedly

58. Melikoff, Au banquet des Quarante, 37-44.

59. Kehl-Bodrogi, Die Kizilbash/Aleviten, 38-47. 
politicized and ethnicized.60 Spearheaded by the new, educated Alevi elite, Alevi cultural associations are established, foundations and trusts organized, old Bektashi convents reopened, saints' tombs rebuilt, rituals restored and re-invented. The overall revival places emphasis on Alevism as a cultural and religious heritage in an effort to reconstruct Alevi culture, community, and identity, but also to articulate Alevi collective interests towards the modern state and demand equality with the Sunni majority. In an ongoing process of negotiation due to the participation of leaders representing different traditions and trends, many intellectuals are making contributions towards a systematization of Alevi belief and a flood of new books and journals reflects the efforts to reinvent Alevism.

Certain actors interpret Alevism as the specifically Turkish form of Islam, that is, the "true" Islam rid of Arab influences. An ethnic dimension is often emphasized, making Alevism a support for Turkish identity or assimilating it to a Kurdish authentic phenomenon. More generally, this view sees Alevism as a Turkish-Anatolian religion combining Islam with elements of Turkish culture, as the authentic expression of an Anatolian culture and civilization. In contrast to a specific Turkish nationalism, an Anatolian cultural mosaic is set up, which includes many other groups allied with the Alevis against Ottoman oppression.

On the other hand, while many remained Kemalist and hoped that the state would officially legitimize the Bektashi order, the new generation showed a strong tendency to think of Alevism as a political opposition rather than a religious tradition. Partly due to the severe repression of the left and partly as a response to the imposition of a conservative brand of Sunni Islam by the state, the young generation joined extreme leftist parties. Working for a radical restructuring of society, they viewed all "reactionary" elements which tried to assimilate them into mainstream Sunni life as enemies, reinterpreting both historical opposition to Sunnism in terms of class struggle and Alevism in socialist and Marxist idioms that seem to have an affinity to Bektashi ideals of equality and traditions of revolt and opposition to the state. 61 They viewed their religion as a positive political and social

60. Krisztina Kehl-Bodrogi, Vom revolutionären Klassenkampf zum "Wahren" Islam: Transformationsprocesse im Alevitum der Turkei nach 1980, Socialanthropologische Arbeitspapiere 49 (Berlin: Freie Universität, 1992); Karin Vorhoff, Zwischen Glaube, Nation und neuer Gemeinschaft: Alevitische Identität in der Türkei der Gegenwart, Islamkundliche Untersuchungen, 184 (Berlin: Klaus Schwarz Verlag, 1995); David Shankland, The Alevis in Turkey: The Emergence of a Secular Islamic Tradition (London: RoutledgeCurzon, 2003); Elise Massicard, L'autre Turquie: Le mouvement aléviste et ses territoires (Paris: Presses universitaires de France, 2005).

61. Vorhoff, Zwischen Glaube, Nation und neuer Gemeinschaft. 
revolutionary ideology fighting against oppression and evil on behalf of the poor and marginalized sectors of society. They thus defined Alevism in the tradition of democracy or as a culture of rebellion, based on the Kizilbash revolts under the Ottoman Empire or on the massive Alevi engagement to the left in contemporary Turkey. Considering that Ali was the defender of the poor and oppressed, and that Hassan and Hussein were the first martyrs in the cause of the dispossessed, they presented Alevism as having always led the fight for liberation against all tyranny, while reactionary Sunnism served the rich and powerful dominant elites.

Still, most Alevis follow the Kemalist secularist ideology and as Alevism becomes more secular, the conception of God becomes almost entirely internalized and conflated with the person in a worldly life.62 Thus, the Sufi cry of ecstasy conflating God and the self, regarded as the pinnacle of profound understanding and conveyed often through a mass of complicated symbolism and secret doctrine, becomes completely routinized, a casual but assertive claim to place the individual and one's desires at the center of the universe. This shift can lead to a profoundly peaceful humanism, and frequently does. It may also lead to a notable phenomenon whereby individuals, or sometimes whole Alevi associations, may interpret Alevism as an international culture. They stress only the liberal and humanistic values of Alevism as a worldview, downplaying its religious connotations. In this case, they would deny that Alevism is Islamic, and claim the origins lie in pre-Islamic religious systems, stressing their links to similar groups, all assumed to be fragments of the original community. For these people, being an Alevi is widened to something that is common to all humanity, not restricted to a chosen group of believers within a wider creed, and in effect, not even to do with religion.

Traditional Alevism was based in closed rural communities and consisted of local, largely orally transmitted traditions, while the new Alevism is based in modern urban associations and is experiencing a rapid process of rationalization and scripturalization. This allowed a redistribution of the knowledge capital to the extent of witnessing the appearance of a new body of exegetes, comparable to a clergy, that is, to use Weberian terms, a group holding the monopoly on the manipulation of the visions of the world. Indeed, knowledge is not only a symbolic capital but represents a prime essential resource, absolutely sacralized by afl political identity actors of Alevism. However, in the course of movement, no consensus has emerged among actors and entrepreneurs who are even aware of their dissension

62. Shankland, The Alevis in Turkey. 
on the origin and the very nature of Alevism. If all are in search of a relevant knowledge, the accounts are so contradictory that they often do not know which to believe. There are so many competing conceptions of what Alevism is or should be that the validity of knowledge can always be called in question. Instead of leading to the unification of the movement, the knowledge contributes thereby to the dispersion of interpretations and the multiplication of conflicts.

However, the persistence of debates and the not-attribution of a fixed meaning of Alevism cannot so much be explained by its syncretistic character, but rather because the knowledge is not yet naturalized and objectified. It can be argued that this state of affairs is due above all to the fact that during the movement no major actor has yet emerged, likely to impose a single interpretation of Alevism in politically relevant categories. This is due to both the configuration of actors and the absence of institutions making it possible to objectify a source of knowledge acceptable and accepted by all.

\section{CONCLUSION}

Clearly the character of Bektashism showed first a cultural system corresponding to the model of religious mediation in which all hierarchies were denied. Such a model is illustrated specifically in the early times of Bektashism in the thirteenth and fourteenth centuries, during the Ottoman-Safavid wars in the first half of the sixteenth century, after the suppression of Janissary troops in the first half of the nineteenth century, or after the abolition of dervish orders in the first half of the twentieth century. It is this emphasis that has made it possible for the Bektashis in Anatolia to achieve a close sense of identity successively with the Young Turk movement, with the Albanian national awakening in the second half of the nineteenth century, 63 or with the early Turkish nationalism in the first quarter of the twentieth century. The same emphasis must have also interacted with more recent nationalist ideals and left-wing "progressive" political philosophy that are even more unstable, as has been often the case with the Alevi revival in contemporary Turkey, or with the "democratic" processes of post-communist transformations in contemporary Albania.

In turn, when the members of the previously persecuted religious minority may already acquire a degree of refigious and political respectability within society at large, the subjective and millenarian doctrines of heterodoxy and liberation theology fade

63. Doja, "A Political History of Bektashism in Albania." 
into the background. In the end, the chances are that the heirs of mystics and the heterodox promoters of spiritual reform and social movement will turn into followers and faithful defenders of a legitimate authority. They will become the spokespeople for an institutionalized orthodoxy whose support will be sought by the political regime.

I believe this process must correspond to the radical change that took place in the Bektashi environment after the organization of the order in the sixteenth century, which may also be discerned each time after recovering from periods of persecution, when the nebulous group of Bektashi dervishes gradually developed into an ecclesiastic institution with a highly organized and centralized hierarchy. All available accounts in the literature clearly show that this process of organizational centralization, coupled with a concomitant process of doctrinal radicalization, was fostered under the specific conditions of Ottoman patronage during the sixteenth and eighteenth centuries, especially after the order became linked to the powerful military body of the Janissaries. As I showed elsewhere, a similar process was once again reiterated in Independent Albania in the twentieth century when Bektashism enjoyed official state recognition.64 Finally, the counter-example of the revival of Alevism in contemporary Turkey shows that, while the Alevis are seeking to organize themselves for their own protection and survival by building up a religious-cultural association, in the process they have not yet established a hierarchy of their own, claiming a "true" faith with its own infallible dogmas and doctrines.

The transition from innovation to conservatism in theological conceptions and organizational structures, and the subsequent renewal of innovation, in support of either liberating social and national movements or the re-establishment of a new political power in society, takes on different forms and tones, forming a complex process requiring detailed historical and political analysis of the cultural values and social entities involved. With these necessary changes, Bektashi religion, rather than seen as an individual life path, must be regarded as the collective subservience to a road, as a religious order headed by authoritarian leadership. Bektashism, henceforth viewed as a revealed religion whose doctrines are literally true, becomes a system of thought which also claims legal authority. The different elements on which this power is based consist of acceptance of the inherent superiority of the Bektashi leaders, the ratification of their decisions at collective rituals, and the inculcation of a sense of appropriate behavior encapsulated within a necessary

64. Ibid. 
moral philosophy. The program as a whole is supported more immediately through a rich corpus of ritual, narrative, poetry, music, and myth.

I have discussed elsewhere the particular affinity that sociologists and anthropologists have always shown between new religious movements and social, cultural and national crisis movements, as well as the extent to which religious ideas must be regarded either as a justification for liberationist movements or as an ideology justifying domination.65 The analysis of doctrinalideological and structural-organizational characteristics of Bektashism throughout its history that is presented here is an illustrative suggestion that it is precisely on these structural and ideological grounds that such a dialectical correlation may be correctly addressed.

65. Doja, "Histoire et dialectique des idéologies et significations religieuses," 677-79. 